\title{
Frog diversity in the Floresta Nacional de Chapecó, Atlantic Forest of southern Brazil
}

\author{
Elaine Maria Lucas ${ }^{1,3}$ \& Vanessa Barbisan Fortes ${ }^{2}$ \\ ${ }^{1}$ Departamento de Ecologia, Instituto de Biociências, \\ Universidade de São Paulo - USP, \\ CP 11461, CEP 05508-900, São Paulo, SP, Brasil, http://www.ib.usp.br \\ ${ }^{2}$ Centro de Ciências Agro-Ambientais e de Alimentos, \\ Universidade Comunitária Regional de Chapecó - Unochapecó, \\ Rua Senador Atílio Fontana, 591E, CEP 89809-000, Chapecó, SC, Brasil, https://www.unochapeco.edu.br \\ ${ }^{3}$ Corresponding author: Elaine Lucas, e-mail: elaine_mlucas@yahoo.com.br
}

LUCAS, E.M. \& FORTES, V.B. Frog diversity in the Floresta Nacional de Chapecó, Atlantic Forest of southern Brazil. Biota Neotrop., 8(3): http://www.biotaneotropica.org.br/v8n3/en/abstract?article+bn00508032008.

\begin{abstract}
The Atlantic Forest is considered one of the world's biological diversity hotspots but is nevertheless increasingly threatened with the rapid destruction and fragmentation of its natural areas. In the state of Santa Catarina, southern Brazil, remnants of the mixed ombrophilous forest and seasonal deciduous forest exist as islands within large areas of agriculture, pastures and human settlements. Here we present information on species richness and habitat use by anurans in the Floresta Nacional de Chapecó, located in the western portion of the state of Santa Catarina. Anurans were surveyed by active search of potential reproductive sites from December 1998 to December 2001. A total of 29 species were recorded, most of which have a known distribution restricted to southern Brazil and adjacent countries (Argentina, Paraguay, and Uruguay) and use open areas for reproduction. The species composition was most similar to other areas of mixed ombrophilous forest and seasonal deciduous forest from the extreme south of Brazil. The information in this study may support the implementation of conservation and management strategies in the area.
\end{abstract}

Keywords: amphibians, habitat use, mixed ombrophilous forest, Santa Catarina, Brazil.

LUCAS, E.M. \& FORTES, V.B. Diversidade de anuros na Floresta Nacional de Chapecó, FlorestaAtlântica do sul do Brasil. Biota Neotrop., 8(3): http://www.biotaneotropica.org.br/v8n3/pt/abstract?article+bn00508032008.

Resumo: A Floresta Atlântica é um dos hotspots mundiais de diversidade biológica, mas se encontra cada vez mais ameaçada devido a rápida destruição e fragmentação das áreas naturais. No Estado de Santa Catarina, os remanescentes de Floresta Atlântica formam ilhas em meio a amplas áreas de cultivo agrícola, pastagens e habitações humanas. Neste estudo, apresentamos informações sobre a riqueza de espécies e uso do ambiente pelos anuros na Floresta Nacional de Chapecó (FNC), localizada nos municípios de Guatambú e Chapecó, Estado de Santa Catarina. A coleta de dados foi realizada entre dezembro de 1998 e dezembro de 2001. Os registros foram realizados por meio de busca ativa em sítios potencialmente utilizados para a reprodução das espécies. Foram registradas 29 espécies de anuros. A maioria das espécies registradas apresenta distribuição geográfica restrita ao sul do Brasil e países vizinhos (Argentina, Paraguai e Uruguai), e utilizam áreas abertas para a reprodução. A composição de espécies da FNC foi mais similar a outras áreas de floresta ombrófila mista e floresta estacional decidual do extremo sul do Brasil. As informações deste estudo podem auxiliar na implementação de estratégias de conservação e manejo da área.

Palavras-chave: anfíbios, uso de ambiente, floresta ombrófila mista, Santa Catarina, Brasil. 


\section{Introduction}

Brazil is the country with the greatest frog diversity in the world, with almost 800 species described (Silvano \& Segalla 2005, SBH 2005). The Atlantic Forest has a significant portion of this diversity as well as a high level of endemism (Silvano \& Segalla 2005). Nearly half the Brazilian species occur in this biome, of which 327 (81\%) are endemic and 137 (34\%) are known only from their type locality (Haddad \& Prado 2005). Nevertheless, the Atlantic Forest is seriously endangered, with only 7 to $8 \%$ of its original cover remaining (Galindo-Leal \& Câmara 2003). Many species were probably eliminated with the fragmentation and loss of natural habitats even before they were known (Morellato \& Haddad 2000). It was estimated that only in the state of Santa Catarina, 2,050 $\mathrm{km}^{2}$ of the Atlantic Forest remnants disappeared between 1985 and 2000 (Hirota 2003). Most of the state is covered by mixed ombrophilous forest, which is one of the most affected and seriously endangered vegetation types in southern Brazil, having been reduced to about $9 \%$ if its original area (Hirota 2003).

In general, few studies of anuran diversity have been carried out in mixed ombrophilous forest and seasonal deciduous forest (e.g. Kwet \& Di-Bernardo 1999, Conte \& Machado 2005, Conte \& Rossa-Feres 2006, Cechin 2002). Studies in the state of Santa Catarina are concentrated in areas of dense ombrophilous forest, in the eastern region of the state (Garcia 1996, Garcia \& Vinciprova 1998, Garcia et al. 2003, Kwet 2006). Due to the scarcity of studies, the remnants of mixed ombrophilous forest and seasonal deciduous forest in the western portion of the state have been indicated as priority areas for herpetofaunistic inventories (Haddad \& Abe 2000).

In this study, we describe the anuran species richness and habitat use by the species in the Floresta Nacional de Chapecó (FNC), a remnant area of the interior Atlantic Forest in southern Brazil. In addition, we characterize the fauna from a biogeographical point of view. Knowledge regarding anuran diversity in the FNC is important in the development of conservation and management strategies for this area.

\section{Materials and Methods}

\section{Study area}

The study was carried out in the Floresta Nacional de Chapecó (FNC), in the western region of the state of Santa Catarina, southern Brazil. The FNC consists of 1.606 ha divided into two areas (Areas I and II, Figure 1). Area I is located in the municipality of Guatambu (27 05' 19.9' $\mathrm{S}$ and 52 46' 47.3" W; $1,297.3$ ha) and Area II, in the municipality of Chapecó ( $27^{\circ} 11^{\prime}$ ' $08.4^{\prime \prime} \mathrm{S}$ and $52^{\circ} 37^{\prime} 09.8^{\prime \prime} \mathrm{W}$; 309.3 ha). According to the Köpen classification, the climate in the region is Cfb, i.e. mesothermal humid subtropical (Nimer 1989). Mean maximum temperature is $19^{\circ} \mathrm{C}$ and mean minimum is $10.1^{\circ} \mathrm{C}$; mean annual precipitation for the period 1973 to 1990 was $1,954 \mathrm{~mm}$, evenly distributed throughout the year (IBAMA 1998). The natural vegetation in the FNC is composed of mixed ombrophilous forest (IBAMA 1998) and seasonal deciduous forest.

About half (46\%) of Area I is occupied by plantations of exotic pine (Pinus elliottii and Pinus taeda), eucalyptus, and Brazilian pine (Araucaria angustifolia), with the remainder composed of native secondary vegetation. There are many small streams with muddy bottoms throughout the area. The most important large river is the Rio Tigre, which contributes for the formation of a reservoir located at the southern edge of the reserve. Two artificial lakes surrounded by grass and with muddy bottoms are located near the administrative headquarters.
Area II has 286.9 ha $(92.7 \%)$ of native forest, 14.2 ha (4.6\%) of exotic pine stands and about 8 ha $(2.6 \%)$ of clearings. The native area is composed of secondary mixed ombrophilous forest, and most of the area planted with exotic pines has an understory of native vegetation. The interior contains springs and small streams with muddy and/or rocky bottoms. There is an artificial lake close to the reserve's access road that has a muddy bottom and is surrounded by grass.

The area sampled was divided into 1) open area, 2) edge and interior of the exotic pine stands, and 3) edge and interior of the native forest. The open areas consist of artificial lakes located in areas exposed to anthropogenic influence. We considered edge areas to be the forest strip (native forest and exotic pine stands) up to $20 \mathrm{~m}$ in from the boundary of the fragment. The bodies of water near the edges were typically artificial lakes, and on rainy days, near small, temporary ponds. The interior of the exotic pine stands contained mud-bottomed streams and temporary ponds, whereas the interior of the native forest, contained streams with muddy or rocky bottoms.

\section{Data collection and analysis}

Field expeditions to the two areas were conducted one day per month during the cold months (May to August) and at least two days per month during the warm months (September to April). In Area I, diurnal and nocturnal samples were conducted from December 1998 to September 2000, and in Area II from October 2000 to December 2001. The species were recorded by means of vocalizations and direct observation of individuals, using headlamps at night (Crump \& Scott 1994). The geographic distribution of the native species was based on information found in the literature (Langone 1994, Kwet \& Di-Bernardo 1999) and databases available on-line (IUCN 2006, Frost 2007).

To check the sufficiency of the samples, species accumulation curves and richness estimators (Chao 2, Jacknife 1, Jacknife 2, Bootstrap), were performed for each sample area, and for both areas together, using the program EstimateS 7.5.0 (Colwell 2005). The sampling units correspond to the months of collection. The constancy of species occurrence was checked using the index $\mathrm{C}$ of Dajoz (1972):

$$
\mathrm{C}=\mathrm{I} \times 100 / \mathrm{L}
$$

where $\mathrm{C}=$ the constancy of species occurrence; $\mathrm{I}=$ number of sampling days on which a species was recorded; and $\mathrm{L}=$ total number of sampling days. Based on the $\mathrm{C}$ values, the following categories were distinguished: constant species (present on more than $50 \%$ of the sampling days), frequent species (present on 25 to $50 \%$ to sampling days, and infrequent species (present on less than $25 \%$ of the sampling days).

The species composition at the Floresta Nacional de Chapecó (Areas I and II) was compared to that from other two localities of mixed ombrophilous forest (Pró-Mata - São Francisco de Paula, RS, Kwet \& Di-Bernardo 1999; Tijucas do Sul, PR, Conte \& Machado 2005); one locality of mixed ombrophilous forest and dense ombrophilous forest (São José dos Pinhais, PR, Conte \& Rossa-Feres 2006); one area of seasonal deciduous forest (Quarta Colônia, RS, Cechin 2002); five areas of dense ombrophilous forest (Goiapaba-Açu, ES, Ramos \& Gasparini 2004; Intervales, Sete Barras, SP, C.F.B. Haddad, unpublished data; Juréia, Iguape, SP, Pombal \& Gordo 2004; Núcleo Santa Virgínia, São Luiz do Paraitinga/Natividade da Serra, SP, C.F.B. Haddad \& M. Hartmann, unpublished data; Picinguaba, SP, Hartmann 2004); three areas of predominantly seasonal semideciduous forest (Atibaia, SP, C.F.B. Haddad, unpublished data; Campinas, SP, C.F.B. Haddad, unpublished data; Serra do Japi, SP, Haddad \& Sazima 1992); three localities of open savannas (Itirapina, SP, Brasileiro et al. 2005; Silvânia, GO, Bastos et al. 2003; Manso, MT, Strussmann 2000); and 

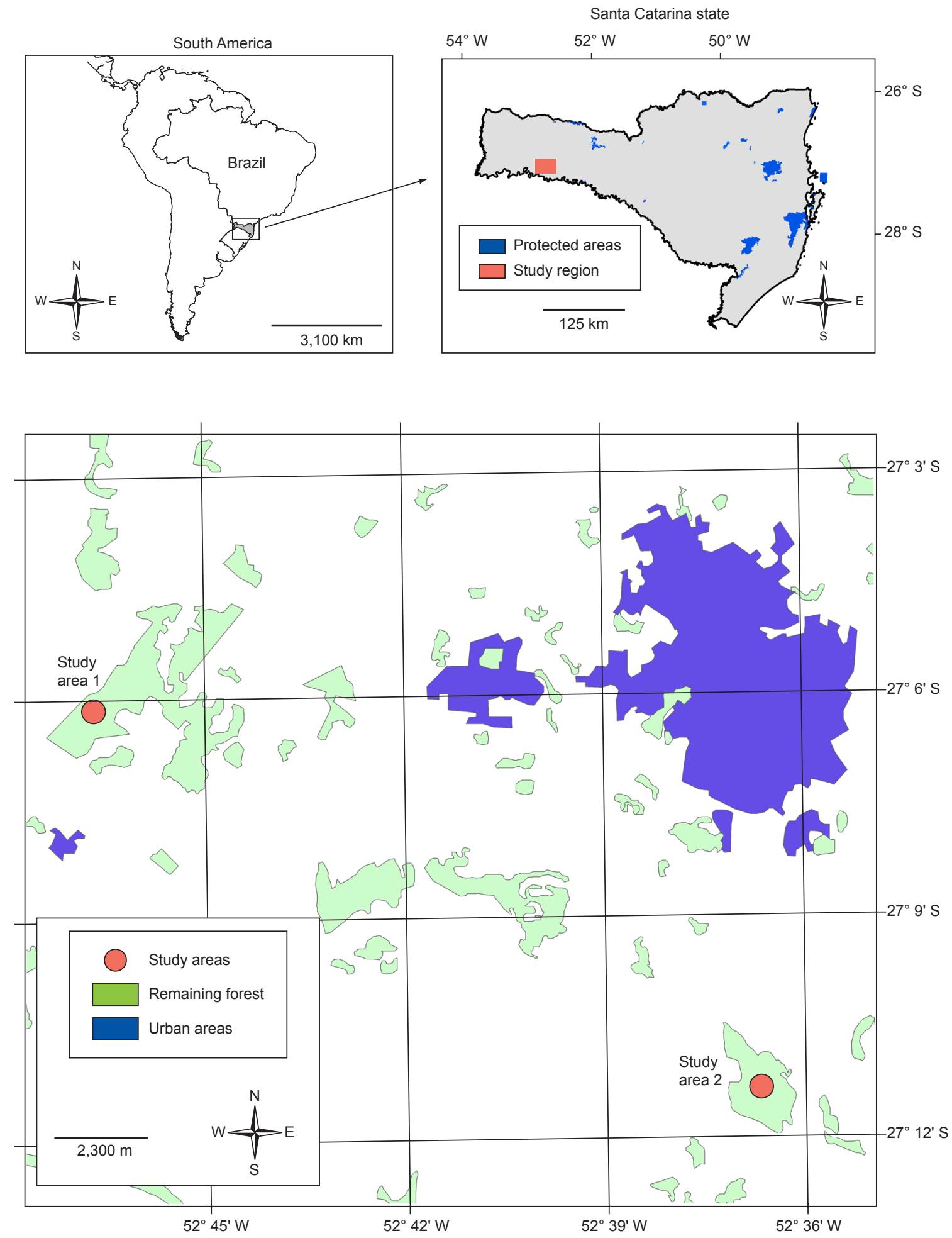

Figure 1. Map of Brazil showing the Floresta Nacional de Chapecó and study sites (Area I - 2705'19.9” S and 52 46’ 47.3" W, municipality of Guatambu, and Area II - $27^{\circ} 11^{\prime} 08.4^{\prime \prime}$ S and 52 $37^{\circ} 09.8^{\prime \prime} \mathrm{W}$, municipality of Chapecó), Santa Catarina state, southern Brazil.

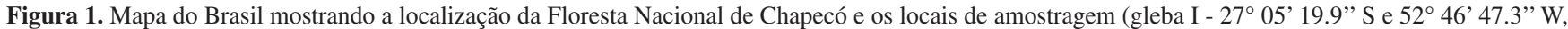

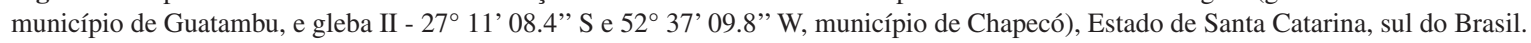

one coastal ecosystem (Lagoa do Peixe, RS, Loebmann \& Vieira 2005). We compared localities with respect to the species composition using the Sorensen coefficient (Wolda 1981) followed by cluster analysis using the WPGMA method (Sneath \& Sokal 1973), implemented in the program MVSP (Kovack 1999). We used linear regression to determine whether the similarity in species composition, measured by the Sorensen coefficient, between the Floresta Nacional de Chapecó and other study areas was related to the linear distance between our 
study area and other areas, with a significance level of $\mathrm{p}<0.05$ (Zar 1999). The reference used for the calculation of the geographical distances was Area I, located about $11 \mathrm{~km}$ from Area II. The analyses were performed using BioEstat 3.0 program (Ayres et al. 1998). The species were identified by specialists, or by the use of identification guides (Straneck et al. 1993, Langone 1994, Kwet \& Di-Bernardo 1999, Achaval \& Olmos 2003) and comparison with specimens deposited in the scientific collections of the Museu de Zoologia da Universidade de São Paulo (MZUSP) and the Coleção Célio Fernando Baptista Haddad (CFBH) of the Universidade Estadual Paulista, Rio Claro, São Paulo state (CFBH). Taxonomic classification of the species followed those suggested by Faivovich et al. (2005) and Frost et al. (2006). Voucher specimens were deposited in the MZUSP and the $\mathrm{CFBH}$.

\section{Results}

Twenty-nine anuran species were recorded, 26 of which were found inside the boundaries of the reserve, and three in the surrounding area. Nineteen species were recorded in Area I and 24 in Area II (Table 1). The species recorded belong to eight families and 15 genera (Table 1): Bufonidae (two genera; three species), Centrolenidae (one

Table 1. Anuran species recorded in Areas I and II at the Floresta Nacional de Chapecó and surrounding area, habitat use, frequency of occurrence from December 1998 to December 2001, and species general geographic distribution pattern. OA = open area; IP = interior of the pine stand; EP = edge of pine stand; $\mathrm{IN}=$ interior of native forest; $\mathrm{EN}=$ edge of native forest; $\mathrm{CT}=$ constant species; FR = frequent species; and IN = infrequent species; W = wide distribution in Brazil and/or South America; $\mathrm{S}=$ distribution restricted to southern Brazil, Argentina, Paraguay, and Uruguay.

Tabela 1. Espécies de anuros registradas nas glebas I e II da Floresta Nacional de Chapecó e arredores, ambiente de registro, frequiência de ocorrência no período de dezembro de 1998 a dezembro de 2001 e padrão geral de distribuição geográfica. OA = área aberta; IP = interior de plantio de Pinus; EP = borda de plantio de Pinus; $\mathrm{IN}=$ interior de floresta nativa; $\mathrm{EN}=$ borda de floresta nativa; $\mathrm{CT}=$ espécies constantes; $\mathrm{ER}=$ espécies freqüentes; $\mathrm{AD}=$ espécies infreqüentes; $\mathrm{W}$ = ampla distribuição geográfica no Brasil e/ou América do Sul; S = distribuição geográfica restrita ao sul do Brasil, Argentina, Paraguai e Uruguai.

\begin{tabular}{|c|c|c|c|c|c|c|c|c|c|c|c|c|}
\hline \multirow[t]{2}{*}{ Family/species } & \multicolumn{2}{|c|}{ Area } & \multicolumn{5}{|c|}{ Habitat } & \multicolumn{3}{|c|}{ Occurrence } & \multicolumn{2}{|c|}{ Distribution } \\
\hline & I & II & $\mathbf{O A}$ & IP & EP & IN & EN & CT & FR & IN & $\mathbf{W}$ & $\mathbf{S}$ \\
\hline \multicolumn{13}{|l|}{ BUFONIDAE } \\
\hline Rhinella henseli (Lutz, 1934) & $\mathrm{x}$ & $\mathrm{x}$ & $\mathrm{x}$ & - & - & - & - & - & - & $\mathrm{x}$ & - & $\mathrm{x}$ \\
\hline Rhinella icterica (Spix, 1824) & $\mathrm{X}$ & $\mathrm{X}$ & $\mathrm{x}$ & - & - & - & - & - & - & $\mathrm{X}$ & $\mathrm{x}$ & \\
\hline Melanophryniscus sp. 1 & - & $\mathrm{x}$ & - & $\mathrm{x}$ & $\mathrm{x}$ & - & - & - & - & $\mathrm{x}$ & - & $\mathrm{x}$ \\
\hline \multicolumn{13}{|l|}{ CENTROLENIDAE } \\
\hline $\begin{array}{l}\text { Hyalinobatrachium uranoscopum } \\
\text { (Muller, 1924) }\end{array}$ & - & $\mathrm{x}$ & - & - & - & $\mathrm{x}$ & $\mathrm{x}$ & - & - & $\mathrm{x}$ & $\mathrm{x}$ & $\mathrm{x}$ \\
\hline \multicolumn{13}{|l|}{ CYCLORAMPHIDAE } \\
\hline $\begin{array}{l}\text { Limnomedusa macroglossa } 2 \\
\text { (Duméril \& Bibron, 1841) }\end{array}$ & - & - & - & - & - & - & - & - & - & - & - & - \\
\hline $\begin{array}{l}\text { Odontophrynus americanus } \\
\text { (Duméril \& Bibron, 1841) }\end{array}$ & $\mathrm{x}$ & $\mathrm{x}$ & $\mathrm{x}$ & $\mathrm{x}$ & $\mathrm{x}$ & - & - & - & - & $\mathrm{x}$ & $\mathrm{x}$ & - \\
\hline Proceratophrys bigibbosa (Peters, 1872) & $\mathrm{x}$ & $\mathrm{x}$ & - & - & - & $\mathrm{x}$ & - & - & - & $\mathrm{x}$ & - & $\mathrm{x}$ \\
\hline \multicolumn{13}{|l|}{ HYLIDAE } \\
\hline Aplastodiscus perviridis Lutz in Lutz, 1950 & $\mathrm{x}$ & $\mathrm{X}$ & - & $\mathrm{x}$ & - & $\mathrm{x}$ & $\mathrm{x}$ & $\mathrm{X}$ & - & - & $\mathrm{x}$ & - \\
\hline Dendropsophus minutus (Peters, 1872) & $\mathrm{x}$ & $\mathrm{x}$ & $\mathrm{x}$ & - & $\mathrm{x}$ & - & $\mathrm{x}$ & $\mathrm{x}$ & - & - & $\mathrm{x}$ & - \\
\hline Hypsiboas aff. semiguttatus 2 & - & - & - & - & - & - & - & - & - & - & $\mathrm{x}$ & - \\
\hline Hypsiboas albopunctatus (Spix, 1824) & $\mathrm{x}$ & - & $\mathrm{x}$ & - & - & - & - & - & - & $\mathrm{x}$ & $\mathrm{x}$ & - \\
\hline Hypsiboas faber (Wied-Neuwied, 1821) & $\mathrm{x}$ & $\mathrm{x}$ & $\mathrm{x}$ & - & $\mathrm{x}$ & - & $\mathrm{x}$ & - & $\mathrm{x} * *$ & $\mathrm{x}^{*}$ & $\mathrm{x}$ & - \\
\hline $\begin{array}{l}\text { Hypsiboas leptolineatus } \\
\text { (Braun \& Braun, 1977) }\end{array}$ & $\mathrm{x}$ & $\mathrm{x}$ & $\mathrm{x}$ & - & - & - & - & $\mathrm{x}^{* *}$ & - & $\mathrm{x}^{*}$ & - & $\mathrm{x}$ \\
\hline $\begin{array}{l}\text { Phyllomedusa tetraploidea } 2 \\
\text { Pombal \& Haddad, } 1992\end{array}$ & - & - & - & - & - & - & - & - & - & - & - & $\mathrm{x}$ \\
\hline Scinax aromothyella (Faivovich, 2005) & $\mathrm{x}$ & $\mathrm{x}$ & $\mathrm{x}$ & $\mathrm{x}$ & $\mathrm{x}$ & - & - & - & - & $\mathrm{x}$ & - & $\mathrm{x}$ \\
\hline Scinax catharinae (Boulenger, 1888) & - & $\mathrm{x}$ & - & $\mathrm{x}$ & $\mathrm{x}$ & - & - & - & - & $\mathrm{x}$ & - & $\mathrm{x}$ \\
\hline Scinax fuscovarius (Lutz, 1925) & $\mathrm{x}$ & $\mathrm{x}$ & $\mathrm{x}$ & - & - & - & - & - & $\mathrm{x}$ & - & $\mathrm{x}$ & - \\
\hline Scinax granulatus (Peters, 1871) & - & $\mathrm{x}$ & - & - & $\mathrm{x}$ & - & - & - & $\mathrm{x}$ & - & - & $\mathrm{x}$ \\
\hline $\begin{array}{l}\text { Scinax perereca } \\
\text { Pombal, Haddad \& Kasahara, } 1995\end{array}$ & - & $\mathrm{x}$ & $\mathrm{x}$ & - & - & - & - & - & $\mathrm{x}$ & - & - & $\mathrm{x}$ \\
\hline
\end{tabular}


Table 1. Continued...

\begin{tabular}{|c|c|c|c|c|c|c|c|c|c|c|c|c|}
\hline \multirow[t]{2}{*}{ Family/species } & \multicolumn{2}{|c|}{ Area } & \multicolumn{5}{|c|}{ Habitat } & \multicolumn{3}{|c|}{ Occurrence } & \multicolumn{2}{|c|}{ Distribution } \\
\hline & I & II & $\mathbf{O A}$ & IP & EP & IN & EN & CT & FR & IN & $\mathbf{W}$ & $\mathbf{S}$ \\
\hline Scinax squalirostris (Lutz, 1925) & - & $\mathrm{x}$ & $\mathrm{x}$ & - & - & - & - & - & - & $\mathrm{x}$ & $\mathrm{X}$ & - \\
\hline \multicolumn{13}{|l|}{ LEIUPERIDAE } \\
\hline Physalaemus cuvieri Fitzinger, 1826 & $\mathrm{x}$ & $\mathrm{x}$ & $\mathrm{x}$ & $\mathrm{x}$ & $\mathrm{x}$ & $\mathrm{x}$ & $\mathrm{x}$ & $\mathrm{x}$ & - & - & $\mathrm{x}$ & - \\
\hline Physalaemus aff. gracilis & $\mathrm{x}$ & $\mathrm{x}$ & $\mathrm{x}$ & $\mathrm{x}$ & $\mathrm{x}$ & $\mathrm{x}$ & $\mathrm{x}$ & $\mathrm{x}$ & - & - & $\mathrm{x}$ & - \\
\hline \multicolumn{13}{|l|}{ LEPTODACTYLIDAE } \\
\hline Leptodactylus fuscus (Schneider, 1799) & $\mathrm{x}$ & $\mathrm{x}$ & $\mathrm{x}$ & - & - & - & - & - & $\mathrm{x}^{*}$ & $\mathrm{x}^{* *}$ & $\mathrm{x}$ & - \\
\hline $\begin{array}{l}\text { Leptodactylus gracilis } \\
\text { (Duméril \& Bibron, 1841) }\end{array}$ & $\mathrm{x}$ & $\mathrm{X}$ & $\mathrm{x}$ & - & - & - & - & - & - & $\mathrm{x}$ & - & $\mathrm{x}$ \\
\hline $\begin{array}{l}\text { Leptodactylus mystacinus } \\
\text { (Burmeister, 1861) }\end{array}$ & $\mathrm{x}$ & - & - & $\mathrm{x}$ & - & - & - & - & - & $\mathrm{x}$ & $\mathrm{x}$ & - \\
\hline Leptodactylus cf. ocellatus & $\mathrm{x}$ & $\mathrm{x}$ & $\mathrm{x}$ & - & - & - & - & $\mathrm{x}$ & - & - & $\mathrm{x}$ & - \\
\hline Leptodactylus plaumanni Ahl, 1936 & $\mathrm{x}$ & $\mathrm{x}$ & $\mathrm{x}$ & - & - & - & - & - & $\mathrm{x}$ & $\mathrm{X}$ & - & $\mathrm{x}$ \\
\hline \multicolumn{13}{|l|}{ MICROHYLIDAE } \\
\hline $\begin{array}{l}\text { Elachistocleis bicolor } \\
\text { (Guérin-Méneville, 1838) }\end{array}$ & $\mathrm{x}$ & $\mathrm{x}$ & $\mathrm{x}$ & - & - & - & - & - & - & $\mathrm{x}$ & - & $\mathrm{x}$ \\
\hline \multicolumn{13}{|l|}{ RANIDAE } \\
\hline Lithobates catesbeianus (Shaw, 1802) & $\mathrm{x}$ & $\mathrm{x}$ & $\mathrm{x}$ & $\mathrm{x}$ & $\mathrm{x}$ & $\mathrm{x}$ & $\mathrm{x}$ & $\mathrm{x}$ & - & - & - & - \\
\hline Total of species & 20 & 24 & 19 & 9 & 10 & 6 & 7 & 7 & 6 & 17 & 15 & 13 \\
\hline
\end{tabular}

1) Species of the tumifrons group, in the process of being described (D. Baldo, unpublished data); and 2) Species recorded outside the boundaries of the FNC; $*$ Area I, $* *=$ Area II.

1) Espécie do grupo tumifrons, em processo de descrição (D. Baldo, com. pessoal); e 2) espécie registrada no entorno da FNC; * = gleba I, ** = gleba II.

genus; one species), Cycloramphidae (three genera; three species), Hylidae (five genera; 13 species), Leptodactylidae (one genus; five species), Leiuperidae (one genus; two species) and Microhylidae (one genus; one species), and one exotic species from the family Ranidae (Lithobates catesbeianus).

Nine species $(34.6 \%$ of the total) were found in all of the environments sampled in the two areas. In the open areas we found 19 species ( $73.1 \%$ of the total), with 12 (46.1\% of the total) being observed exclusively in this environment (Table 1). In the area of exotic pine stands, nine species $(34.6 \%)$ were observed at the edges, and nine $(34.6 \%)$ in the interior of the stands. In the native forest, seven species (26.9\%) were found at the edges and seven $(26.9 \%)$ in the interior (Table 1). In the interior of the native forest we recorded Scinax catharinae, Proceratophrys bigibbosa, Hyalinobatrachium uranoscopum, Physalaemus cuvieri, Aplastodiscus perviridis and, on one occasion, we found the exotic species Lithobates catesbeianus. Scinax catharinae was also recorded in a stream inside the exotic pine stand with a sub-forest of native vegetation. Only P. bigibbosa and $H$. uranoscopum were found exclusively in the interior of the native forest areas, in streams in Areas I and II, respectively. Proceratophrys bigibbosa occurred in a mud-bottomed stream and Hyalinobatrachium uranoscopum was found in a stream with a rocky bottom, which stretches from the FNC flows through an open area. Few individuals (two to five) of $H$. uranoscopum were observed in a small stretch of the stream (about $100 \mathrm{~m}$ ).

According to the Dajoz index (1972), in Area I, five species were constant, four were frequent, and nine were infrequent (Table 1). In Area II, six species were constant, five were frequent, and three were infrequent (Table 1). The species accumulation curves showed that the sampling time was not enough to record all species in the two areas separately, but showed a strong tendency toward stabilization when the two areas are considered together (Figure 2). All the values provided by the estimators were near the observed richness (Areas I e II; Figure 2).

The FNC had more species in common with the Pró-Mata $(n=18)$ and the Quarta Colônia $(\mathrm{n}=15)$ areas, both located in the state of Rio Grande do Sul, in southern Brazil. The cluster analysis showed greater similarity with the Pró-Mata area, but also showed a close relation with two other areas in Rio Grande do Sul, Quarta Colônia and Lagoa do Peixe (Figure 3 ). The closest areas showed greatest similarity in species composition $\left(r^{2}=0.49 ; \mathrm{p}<0.01\right.$; Figure 4$)$.

The exotic species Lithobates catesbeianus was very common at the two study areas and was the most recorded species. This species was observed reproducing throughout the year, including the coldest months (June and July).

\section{Discussion}

The 29 anuran species recorded in the FNC represent approximately $7.2 \%$ of the total anuran richness known for the Atlantic Forest (405 species), and about $60 \%$ of the species expected to occur in the western region of Santa Catarina, according to the Global Amphibian Assessment database (IUCN 2006; about 50 species). The total number of species recorded is similar to that observed in other areas of mixed ombrophilous forest with similar sampling periods (Table 3; see also Conte \& Rossa-Feres 2006), although the accumulation curves 

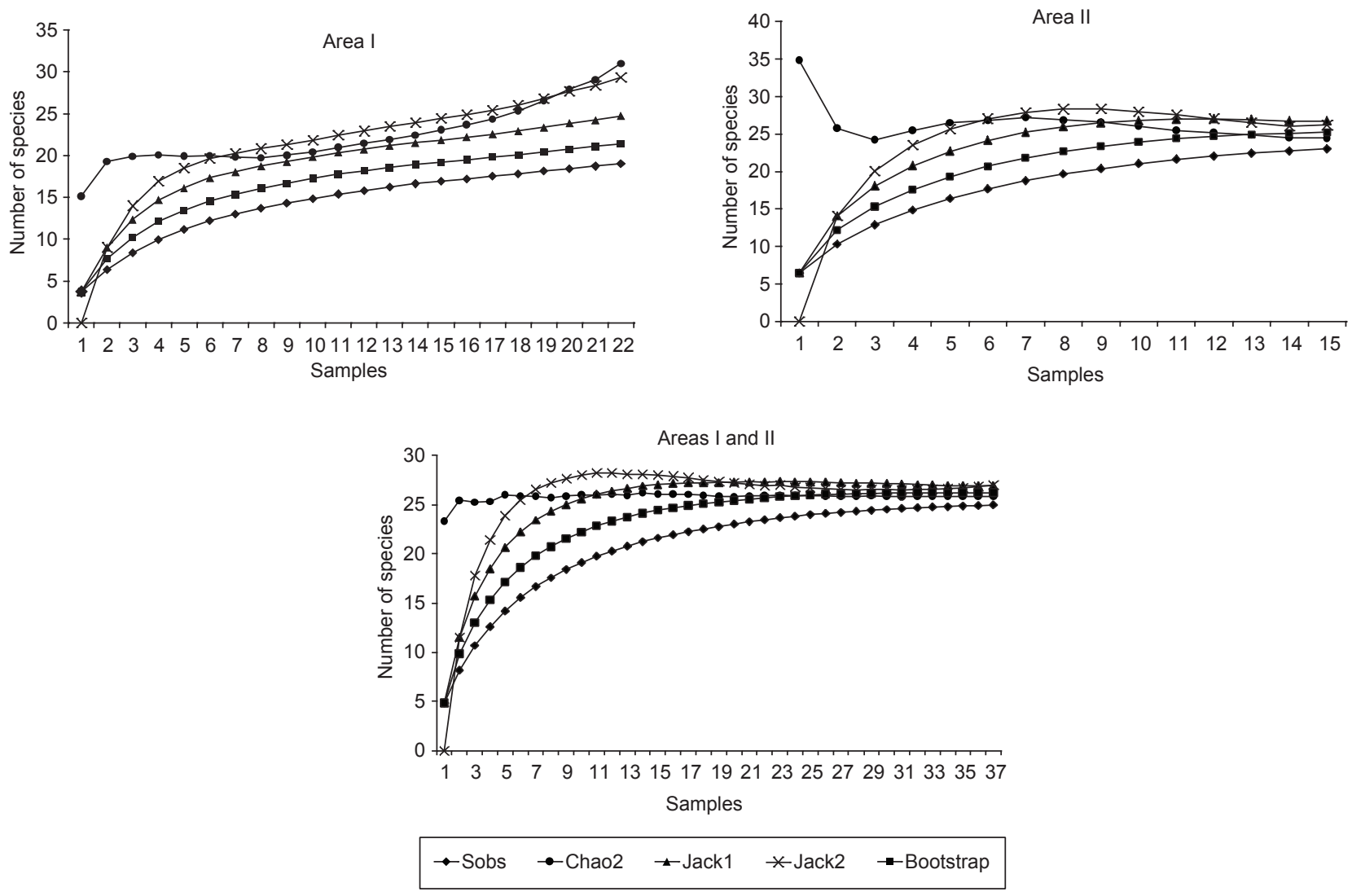

Figure 2. Species accumulation curves, calculated from data collected from December 1998 to December 2001 and estimators Chao 2, Jacknife 1, Jacknife 2 and Bootstrap to the Areas I, II and both, at the Floresta Nacional de Chapecó, SC. The circles correspond to the mean of 1000 points generated with randomly ordered samples.

Figura 2. Curvas de acumulação de espécies, calculadas com os dados obtidos entre dezembro de 1998 e dezembro de 2001 e estimadores de riqueza Chao 2 , Jacknife 1, Jacknife 2 e Bootstrap para as glebas I, II e ambas, na Floresta Nacional de Chapecó, SC. Os pontos correspondem à média das 1.000 curvas geradas com ordem aleatória de amostras.

Table 2. Observed and estimated species richness in Areas I and II of the Floresta Nacional de Chapecó, SC.

Tabela 2. Riqueza de espécies observada e estimada para as glebas I and II na Floresta Nacional de Chapecó, SC.

\begin{tabular}{lccc}
\hline \multicolumn{1}{c}{ Estimator } & Area I & Area II & $\begin{array}{c}\text { Combined } \\
\text { areas }\end{array}$ \\
\hline Observed richness & 20 & 24 & 26 \\
Chao 2 & 31 & 24 & 25 \\
Jacknife 1 & 25 & 27 & 27 \\
Jacknife 2 & 29 & 26 & 27 \\
Bootstrap & 21 & 25 & 26 \\
\hline
\end{tabular}

for each area had not yet stabilized. In fact, there are environments in the two areas of the FNC that have not been surveyed, which may shelter anuran species not yet recorded, however, the estimated and observed richness are similar. Based on the geographic distribution of the species and the analysis of similarity in species composition among formations that are similar and different from that sampled in this study, we conclude that the anuran fauna recorded in this study is characteristic of the southern region of Brazil and South America, with a significant portion of species associated with open areas.
About half of the species recorded in the FNC $(57 \% ; \mathrm{n}=16)$ are restricted to southern Brazil and adjacent countries (Argentina, Paraguay, and Uruguay; Table 1). Of these 16 species, four (Hyalinobatrachium uranoscopum, Phyllomedusa tretraploidea, Hypsiboas aff. semiguttatus and Scinax catharinae) occur only in the Atlantic Forest domain, whereas the other 12 also occur in the sub-tropical grasslands domain (southern Brazil and Uruguay). Scinax catharinae, Rhinella henseli, Hypsiboas leptolineatus and Leptodactylus plaumanni are restricted to southern Brazil. The remaining species $(43 \%, \mathrm{n}=12)$ are widely distributed in Brazil and other South American countries (Table 1), occurring both in forest and open (grasslands) biomes.

The known geographic distribution (Frost 2007) of four species was extended by this study. Scinax catharinae was only known from the Atlantic Forest in southeastern Brazil, and its record in the FNC extends its known distribution to the inland Atlantic Forest formations. Proceratophrys bigibbosa was only known from Rio Grande do Sul and Argentina; Scinax perereca was only known from São Paulo, Rio Grande do Sul, Argentina and Paraguay, and Scinax granulatus from Argentina, Uruguay and Rio Grande do Sul.

According to the categories of endangered species considered by the Global Amphibian Assessment (IUCN 2006), of the anuran species that occur in FNC, only Proceratophrys bigibbosa is categorized as "Nearly endangered" (IUCN 2006), and the others are 
Frog diversity in the Floresta Nacional de Chapecó

Table 3. Anuran species richness, sampling effort (months surveyed), and size of the study area in localities dominated by mixed ombrophilous forest.

Tabela 3. Riqueza de espécies de anuros, esforço amostral (meses de estudo) e o tamanho da área de estudo em localidades com predominância de floresta ombrófila mista.

\begin{tabular}{lcccc}
\hline \multicolumn{1}{c}{ Locale } & $\begin{array}{c}\text { Size of } \\
\text { area (ha) }\end{array}$ & $\begin{array}{c}\text { Sampling time } \\
\text { (N months) }\end{array}$ & $\begin{array}{c}\text { Number of } \\
\text { species }\end{array}$ & Reference \\
\hline FNC Area I & 1.297 & 22 & 20 & Present study \\
FNC Area II & 309 & 15 & 24 & Present study \\
São Francisco de Paula, RS (Pró-Mata) & Aprox. 4.500 & 48 & 36 & Kwet \& Di-Bernardo 2001 \\
São José dos Pinhais, PR & - & 16 & 34 & Conte \& Rossa-Feres 2006 \\
Tijucas do Sul, PR & - & 12 & 23 & Conte \& Machado 2005 \\
\hline
\end{tabular}

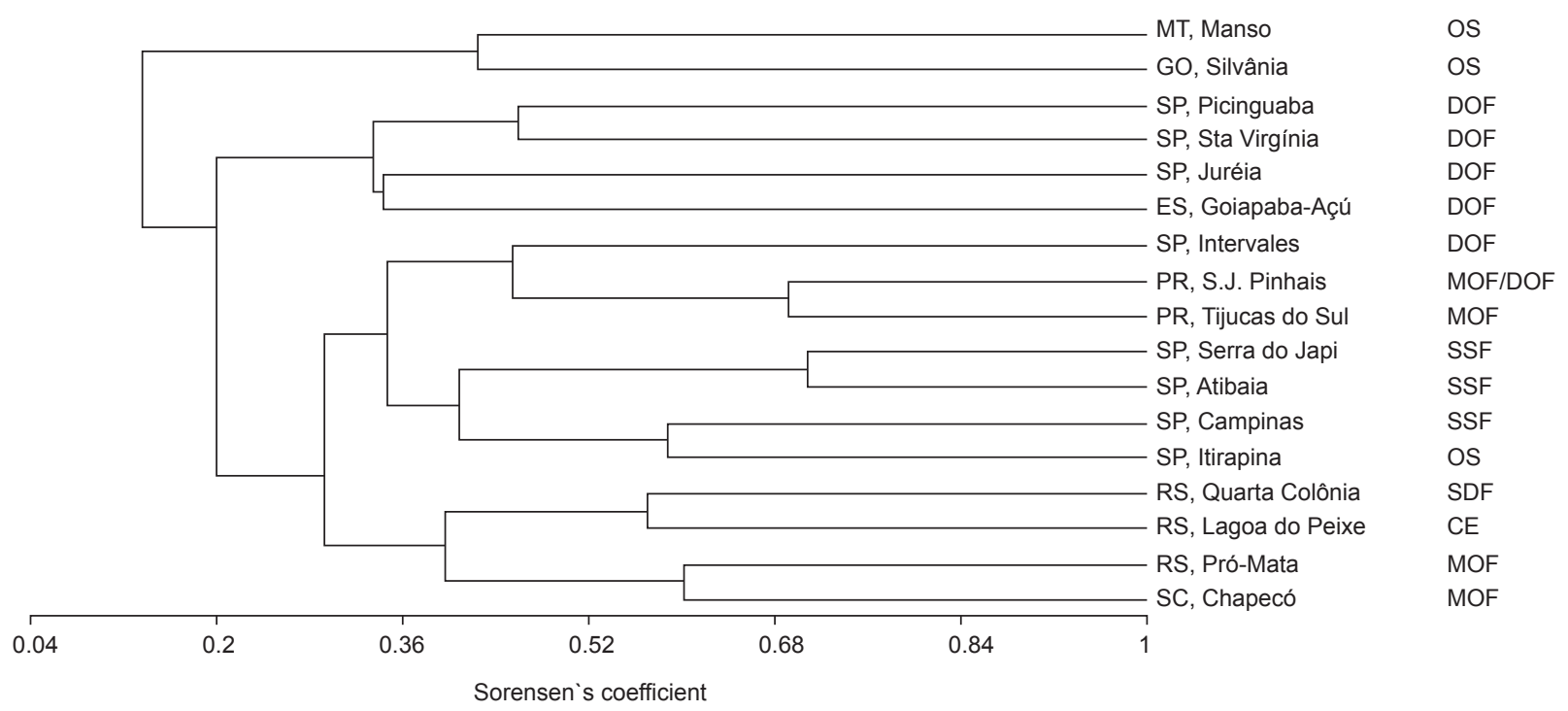

Figure 3. Anuran species composition similarity among localities based on cluster analysis. Geographic location: ES = Espírito Santo state, GO = Goiás state, MT = Mato Grosso state, $\mathrm{PR}=$ Paraná state, $\mathrm{RS}=$ Rio Grande do Sul state, $\mathrm{SC}=$ Santa Catarina state, $\mathrm{SP}=$ São Paulo state. Formation/ecossystem: MOF = mixed ombrophilous forest, $\mathrm{DOF}=$ dense ombrophilous forest, $\mathrm{SDF}=$ seasonal deciduous forest, $\mathrm{SSF}=$ seasonal semideciduous forest, $\mathrm{OS}=$ open savannas, $\mathrm{CE}=$ coastal ecosystem.

Figura 3. Similaridade na composição da anurofauna entre as localidades, baseada em análise de cluster. Localização geográfica das áreas: ES = Espírito Santo, GO = Goiás, MT = Mato Grosso, PR = Paraná, RS = Rio Grande do Sul, SC = Santa Catarina, SP = São Paulo. Formação/ecossistema: MOF = floresta ombrófila mista, $\mathrm{DOF}=$ floresta ombrófila densa, $\mathrm{SDF}=$ floresta estacional decidual, $\mathrm{SSF}=$ floresta estacional semidecidual, $\mathrm{OS}=\mathrm{Cerrado}, \mathrm{CE}=\mathrm{ecossistema}$ costeiro.

classified as 'Least Concern'. None of the species recorded in this study are included in the Brazilian list of endangered species (Lista Nacional das Espécies da Fauna Brasileira Ameaçadas de Extinção - IBAMA 2003).

The cluster analysis showed that, among areas of the same physiognomy, those that are the closest geographically tend to have the greatest similarity in species composition. For example, two sets of localities of mixed ombrophilous forest could be observed: one formed of localities in the state of Paraná (Tijucas do Sul and São José dos Pinhais) and the other of localities in the state of Santa Catarina (present study) and Rio Grande do Sul (Pró-Mata).

The species richness in Area II was slightly greater than in Area I (Table 1) despite the shorter sample time and smaller area, but the difference was not significant. Area II has a greater diversity of environments that can apparently be used by a greater number of anurans. The higher species richness observed in the artificial lakes in open areas $(n=20)$, compared to the exotic pine stands $(n=12)$ and native forest $(n=9)$, may be due to the use of these bodies of water as reproductive sites, since the reproductive mode of the species recorded there depends on the presence of lentic water bodies (Haddad \& Sawaya 2000, Duellman \& Trueb 1994). Because males of these species vocalize during the reproductive activity, it could be easier to find species in the open areas than in the other areas. Some of the species that reproduce in open areas may find occasional or temporary shelter in forests out of the reproductive period, and hence the species richness in forests may be greater than that reported here.

Physalaemus cuvieri, Physalaemus aff. gracilis and the exotic species Lithobates catesbeianus were found in all habitats studied, indicating that these species are generalists. The constant presence of Lithobates catesbeianus in all environments sampled in the two areas corresponds to the pattern observed by Fortes et al. (2004) for the entire municipality of Chapecó. Fortes et al. (2004) showed that the species is very abundant in the region and suggested that its introduction may be causing a negative impact on populations of native species. 


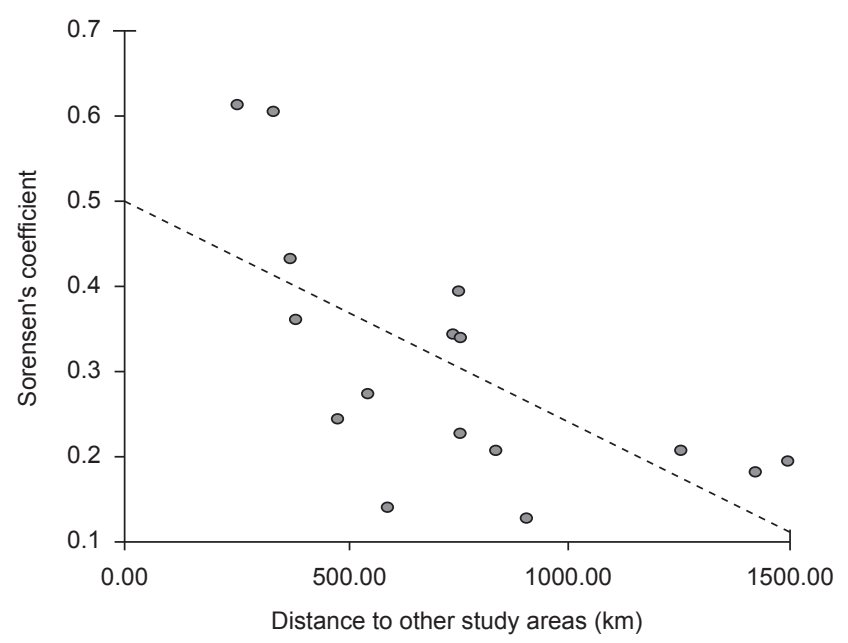

Figure 4. Linear regression between the Sorensen similarity coefficient and the distances between the Floresta Nacional de Chapecó and the 16 areas where species composition was compared.

Figura 4. Regressão entre o índice de similaridade Sorensen e a distância entre a Floresta Nacional de Chapecó e as 16 localidades cujas taxocenoses foram comparadas.

Hypsiboas aff. semiguttatus and Phyllomedusa tetraploidea possibly occur inside the boundaries of the reserve, as habitats used by the species are known to occur inside the study areas (Pombal \& Haddad 1992; E.M. Lucas, pers. obs.). The occurrence of Limnomedusa macroglossa in the two areas is unlikely, as the study areas lack the type of habitat in which this species is usually found (generally rocks along river banks; Straneck et al. 1993). Hyalinobatrachium uranoscopum was recorded only in a small stretch of the stream in Area II. However, this species has not been observed again at this site or in similar environments inside the reserve for two consecutive years after the study period (E. M. Lucas, pers. obs.). Considering the high degree of destruction of natural environments in the region, as well as in the Atlantic Forest as whole (Pinto \& Brito 2005), other areas in the municipalities of Chapecó, Guatambu, and surrounding localities should be studied and protected to preserve local biodiversity.

Considering their size, as well as the anthropogenic pressure to which the two areas in the FNC are subjected, the species richness of anuran amphibians observed can be considered high. These areas represent virtually the last fragments of natural vegetation in the region, where the conservation situation can be considered critical. The conservation of these remnants and incentives to continue studying the native species of fauna and flora, are therefore highly recommended.

\section{Acknowledgements}

We thank Paulo C. A. Garcia and Marcos Di-Bernardo (in memorian) for the assistance with identification of the species; Marcio Martins and Cinthia A. Brasileiro for comments on a preliminary version of the manuscript; Célio F. B. Haddad for providing unpublished lists of species; Gelson Campos, Adriana Branco, Eliara S. Müller, Fabiane Alves, Camile Pandolfo and many other colleagues for their invaluable assistance with the fieldwork; the Instituto Brasileiro de Recursos Naturais Renováveis - IBAMA for authorizing the work in the Floresta Nacional de Chapecó; the $8^{\circ}$ Batalhão da Polícia Militar de Chapecó for logistical support in the field in area II; Milton Cezar Ribeiro for the map of the study area; Anne Kepple for the English version and two anonymous reviewers for contributions.

\section{References}

ACHAVAL, F. \& OLMOS, A. 2003. Anfibios y Reptiles del Uruguay. $2^{\mathrm{a}}$ ed. Graphis Impressora, Montevideo, Uruguay.

AYRES, M., AYRES-Jr, M.A., AYRES, D.L. \& DOS SANTOS, A.S. 1998. BioEstat: aplicações estatísticas nas áreas das ciências biológicas e médicas. Sociedade Civil Mamirauá, Manaus. 193p. Publicações avulsas Mamirauá. (acompanha CD - ROM)

BASTOS, R.P., MOTTA, J.A.O., LIMA, L.P. \& GUIMARÃES, L.D. 2003. Anfíbios da Floresta Nacional de Silvânia, Estado de Goiás R.P. Bastos, Goiânia.

BRASILEIRO, C.A., SAWAYA, R.J., KIEFER, M.C. \& MARTINS, M. 2005. Amphibians of an open Cerrado fragment in southeastern Brazil. Biota neotrop. 5(2): http://www.biotaneotropica.org.br/v5n2/pt/ abstract?article+BN00405022005 (último acesso em 15/07/2007).

CECHIN, S.Z. 2002. Anfíbios. In Quarta Colônia: inventários técnicos (J. Itaqui, coord.). Condesus Quarta Colônia, Santa Maria. p.201-205.

COLWELL, R.K. 2005. Estimates: statistical estimation of species richness and shared species from samples. Version 7.5. User's Guide and application published at: http://viceroy.eeb.uconn.edu/estimates. (último acesso em 24/06/2007)

CONTE, C.E. \& MACHADO, R.A. 2005. Riqueza de espécies e distribuição espacial e temporal em comunidade de anuros (Amphibia, Anura) em uma localidade de Tijucas do Sul, Paraná, Brasil. Rev. bras. zool. 22(4):940-948.

CONTE, C.E. \& ROSSA-FERES, D.C. 2006. Diversidade e ocorrência temporal da anurofauna (Amphibia, Anura) em São José dos Pinhais, Paraná, Brasil. Rev. bras. zool. 23(1):162-175.

CRUMP, M.L. \& SCOTT JR, N.J. 1994. Visual encounter surveys. In Measuring and monitoring biological diversity - standard methods for amphibians (W.R. HEYER, M.A. DONNELLY, W.R. MCDIARMID, L.A.C. HAYECK \& M.S. FOSTER, eds). Smithsonian Institution Press, Washington, p.84-92.

DAJOZ, R. 1972. Ecologia Geral. Vozes;Universidade de São Paulo, Petrópolis; São Paulo.

DUELLMAN, W.E. \& TRUEB, L. 1994. Biology of Amphibians. McGraw-Hill Book Company, New York.

FAIVOVICH, J., HADDAD, C.F.B., GARCIA, P.C.A., FROST, D.R., CAMPBELL, J.A. \& WEELER, W.C. 2005. Systematic review of the frog family Hylidae, with special reference to Hylinae: phylogenetic analysis and taxonomic revision. B Am. Mus. Nat. Hist. (294):1-240.

FORTES, V.B., GONSALES, E.M.L., BRANCO, A., ALVES, F.C. \& MARTINS, A.K. 2004. Perigo: anfíbio exótico ameaça biodiversidade brasileira. Revista Sul Ambiental 4(10):1-3.

FROST, D.R. 2007. Amphibian species of the world: An online reference. American Museum of Natural History, New York, USA. http:// research.amnh.org/herpetology/amphibia/index.html. (último acesso em 15/07/2007).

FROST, D.R., GRANT, T., FAIVOVICH, J., BAIN, R.H., HAAS, A., HADDAD, C.F.B., DE SÁ, R.O., CHANNING, A., WILKINSON, M., DONNELLAN, S.C., RAXWORTHY, C.J., CAMPBELL, J.A., BLOTTO, B.L., MOLER, P., DREWES, R.C., NUSSBAUM, R.A., LYNCH, J.D., GREEN, D.M. \& WEELER, W.C. 2006. The amphibian tree of life. B Am. Mus. Nat. Hist. (297):1-370.

GALINDO-LEAL, C. \& CÂMARA, I.G. 2003. Atlantic Forest Hotspot Status: An Overview. In The Atlantic Forest of South America: Biodiversity Status, Threats, and Outlook (C. GALINDO-LEAL \& I.G. CÂMARA, eds). Center for Applied Biodiversity Science and Island Press, Washington, D.C., p.3-11.

GARCIA, P.C.A. 1996. Nova espécie de Eleutherodactylus Duméril \& Bibron, 1891 (Amphibia, Anura, Leptodactylidae) do Estado de Santa Catarina, Brasil. Biociências 4(2):57-68.

GARCIA, P.C.A. \& VINCIPROVA, G. 1998. Range extensions of some anuran species for Santa Catarina and Rio Grande do Sul States, Brazil. Herpetol. rev. 29(2):117-118. 
GARCIA, P.C.A., VINCIPROVA, G. \& HADDAD, C.F.B. 2003. The taxonomic status of Hyla pulchella joaquini B. Lutz, 1968 (Anura: Hylidae), with description of tadpole, vocalization, and comments on its relationships. Herpetologica 52(3):350-364.

HADDAD, C.F.B. \& SAZIMA, I. 1992. Anfíbios anuros da Serra do Japi. In História Natural da Serra do Japi: ecologia e preservação de uma área florestal no sudeste do Brasil (L.P.C. MORELLATO, coord.). Unicamp/ Fapesp, Campinas, p.188-211.

HADDAD, C.F.B. \& ABE, A.S. 2000. Workshop Mata Atlântica e Campos Sulinos. Anfíbios e Répteis: http://www.conservation.org.br/ma/ (último acesso em 16/06/2006).

HADDAD, C.F.B. \& SAWAYA, R.J. 2000. Reproductive modes of Atlantic Forest hylid frogs: a general overview and the description of a new mode. Biotropica 32(4b):862-871.

HADDAD, C.F.B. \& PRADO, C.P.A. 2005. Reproductive modes in frogs and their unexpected diversity in the Atlantic Forest of Brazil. BioScience 55(3):207-217.

HARTMANN, M.T. 2004. Biologia reprodutiva de uma comunidade de anuros (Amphibia) na Mata Atlântica (Picinguaba, Ubatuba, SP). Tese de Doutorado, Universidade Estadual Paulista 'Julio de Mesquita Filho', Rio Claro, São Paulo.

HIROTA, M.M. 2003. Monitoring the Brazilian Atlantic Forest Cover. In The Atlantic Forest of South America: Biodiversity Status, Threats, and Outlook (C. GALINDO-LEAL \& I.G. CÂMARA, eds). Center for Applied Biodiversity Science and Island Press, Washington, D.C., p.60-65.

IBAMA. Instituto Brasileiro do Meio Ambiente e dos Recursos Naturais Renováveis. 1998. Plano de Manejo da Floresta Nacional de Chapecó. Chapecó, SC.

IBAMA. Instituto Brasileiro do Meio Ambiente e dos Recursos Naturais Renováveis. 2003. Instrução Normativa n ${ }^{\circ}$ 3, de 27 de maio de 2003. Lista das Espécies da Fauna Brasileira Ameaçada de Extinção. IBAMA, Brasília.

IUCN. Conservation International, and NatureServe. 2006. Global Amphibian Assessment: http//www.globalamphibians.org (último acesso em 03/04/2007)

KOVACK, W.L. 1999. MVSP - A multi-variate statistical package for windows. Versão 3.1. Kovack Computing Services, Pentchraeth.

KWET, A. \& DI-BERNARDO, M. 1999. Pró-Mata-Anfíbios. Amphibien. Amphibians. EDIPUCRS, Porto Alegre.

KWET, A. 2006. Bioacoustics in the genus Adenomera (Anura: Leptodactylidae) from Santa Catarina, southern Brazil. Proceedings of the 13th Congress of the Societas Europaea Herpetologica, p. 77-80.
LANGONE, J.A. 1994. Ranas y sapos del Uruguay (reconocimiento y aspectos biológicos). Serie Divulgación. Museo Damaso Antonio Larrañaga, Montevideo. vol.5, p. 1-123.

LOEBMANN, D. \& VIEIRA, J.P. 2005. Relação dos anfíbios do Parque Nacional da Lagoa do Peixe, Rio Grande do Sul, Brasil. Rev. bras. zool. 22(2):339-341

MORELLATO, L.P.C. \& HADDAD, C.F.B. 2000. Introduction: the Brazilian Atlantic Forest. Biotropica 32(4b):786-792

NIMER, E. 1989. Climatologia da região Sul. In Climatologia do Brasil (E. Nimer, ed). IBGE - Depto. de Recursos Naturais e Estudos Ambientais, Rio de Janeiro, p. 195-264.

PINTO, L.P. \& BRITO, M.C.W. 2005. Dinâmica da perda da biodiversidade na Mata Atlântica brasileira: uma introdução. In Mata Atlântica: biodiversidade, ameaças e perspectivas (C. GALINDO-LEAL \& I.G. CÂMARA, eds). Fundação SOS Mata Atlântica/Conservação Internacional, São Paulo. p. 27-30.

POMBAL JR, J.P. \& GORDO, M. 2004. Anfíbios Anuros da Juréia. In Estação Ecológica Juréia-Itatins: Ambiente Físico, Flora e Fauna (O.A.V. MARQUES \& W. DULEBA, eds). Holos, Ribeirão Preto. p. 243-256.

POMBAL JR, J.P. \& HADDAD, C.F.B. 1992. Espécies de Phyllomedusa do grupo burmeisteri do Brasil oriental, com descrição de uma espécie nova (Amphibia, Hylidae). Rev. Bras. Biol. = Braz. J. Biol. 52(2):217-229.

RAMOS, A.D. \& GASPARINI, J.L. 2004. Anfíbios do Goiapaba-Açu. Santo Antônio, Vitória.

SBH. 2006. Lista de espécies de anfíbios do Brasil. Sociedade Brasileira de Herpetologia (SBH): http://www.sbherpetologia.org.br/checklist/anfibios. htm (último acesso em 28/08/2006).

SILVANO, D.L. \& SEGALA, M.V. 2005. Conservação de anfíbios no Brasil. Megadiversidade 1(1):79-86.

SNEATH, P.H.A. \& SOKAL, R.R. 1973. Numerical Taxonomy. Free-man, San Francisco.

STRANECK, R., DE OLMEDO, E.V. \& CARRIZO, G.R. 1993. Catalogo de voces de anfíbios argentinos. Tomo I. Ediciones LOLA, Buenos Aires.

STRUSSMANN, C. 2000. Herpetofauna. In Fauna Silvestre da região do Rio Manso-MT (C.J.R. ALHO, ed). Ibama, Brasília.

WOLDA, H. 1981. Similarity indices, sample size and diversity. Oecologia 50:296-302.

ZAR, J. 1999. Biostatiscal analysis. Upper Saddle River Prentice Hall, New Jersey.

Recebido em 20/11/07

Versão Reformulada recebida em 25/06/08

Publicado em 01/07/08 

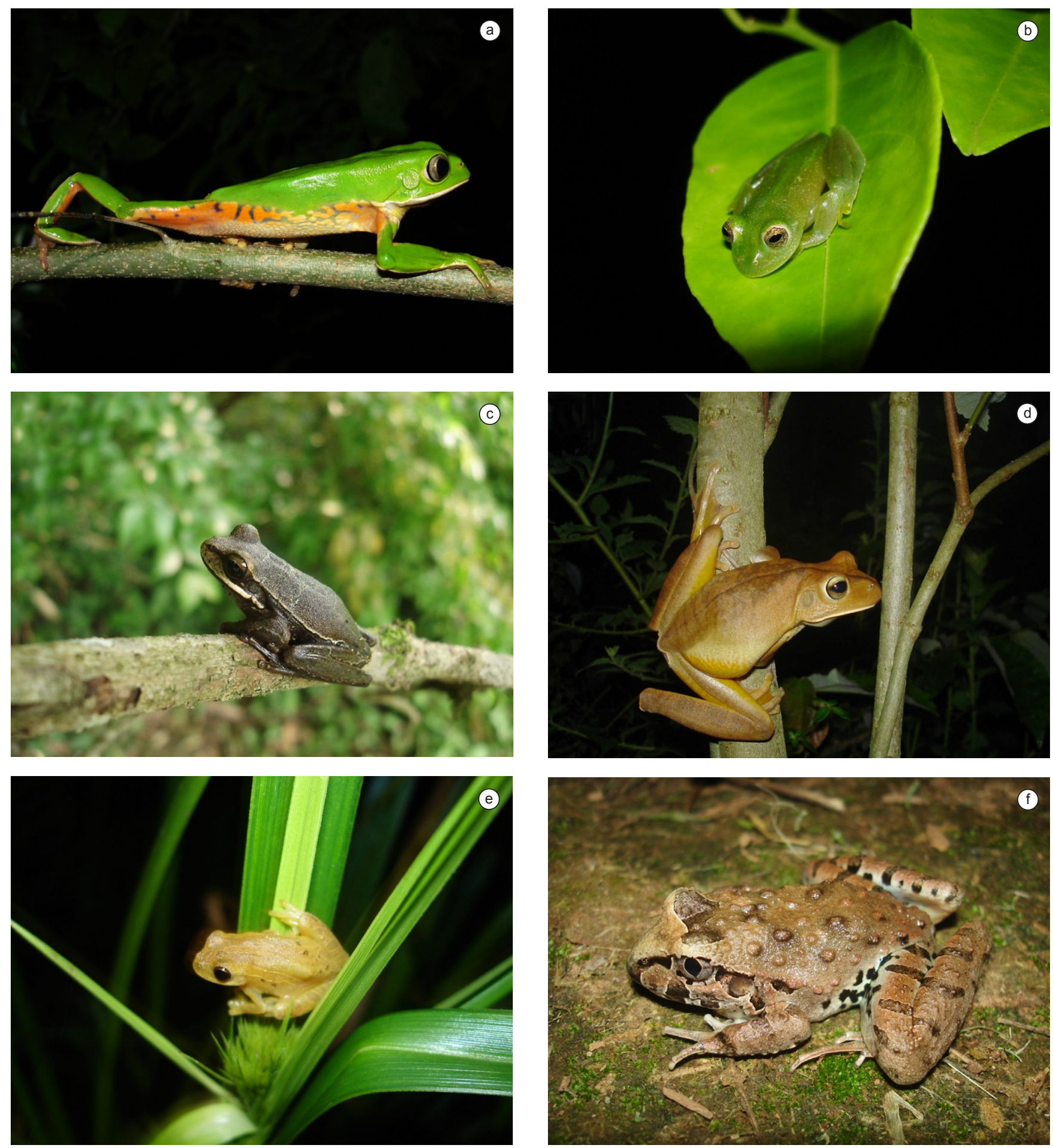

Appendix 1. Amphibian anuran species found in Floresta Nacional de Chapecó, Santa Catarina State, southern Brazil. a) Phyllomedusa tetraploidea, b) Hyalinobatrachium uranoscopum, c) Hypsiboas aff. semigutattus, d) Hypsiboas faber, e) Dendropsophus minutus, f) Limnomedusa macroglossa, g) Scinax fuscovarius, h) Scinax aromothyella, i) Leptodactylus cf. ocellatus, j) Aplastodiscus perviridis, k) Rhinella henseli, and 1) Proceratophrys bigibbosa. Photos: E.M. Lucas.

Apêndice 1. Anfíbios anuros registrados na Floresta Nacional de Chapecó, Estado Santa Catarina, sul do Brasil. a) Phyllomedusa tetraploidea, b) Hyalinobatrachium uranoscopum, c) Hypsiboas aff. semigutattus, d) Hypsiboas faber, e) Dendropsophus minutus, f) Limnomedusa macroglossa, g) Scinax fuscovarius, h) Scinax aromothyella, i) Leptodactylus cf. ocellatus, j) Aplastodiscus perviridis, k) Rhinella henseli, e 1) Proceratophrys bigibbosa. Fotos: E.M. Lucas. 

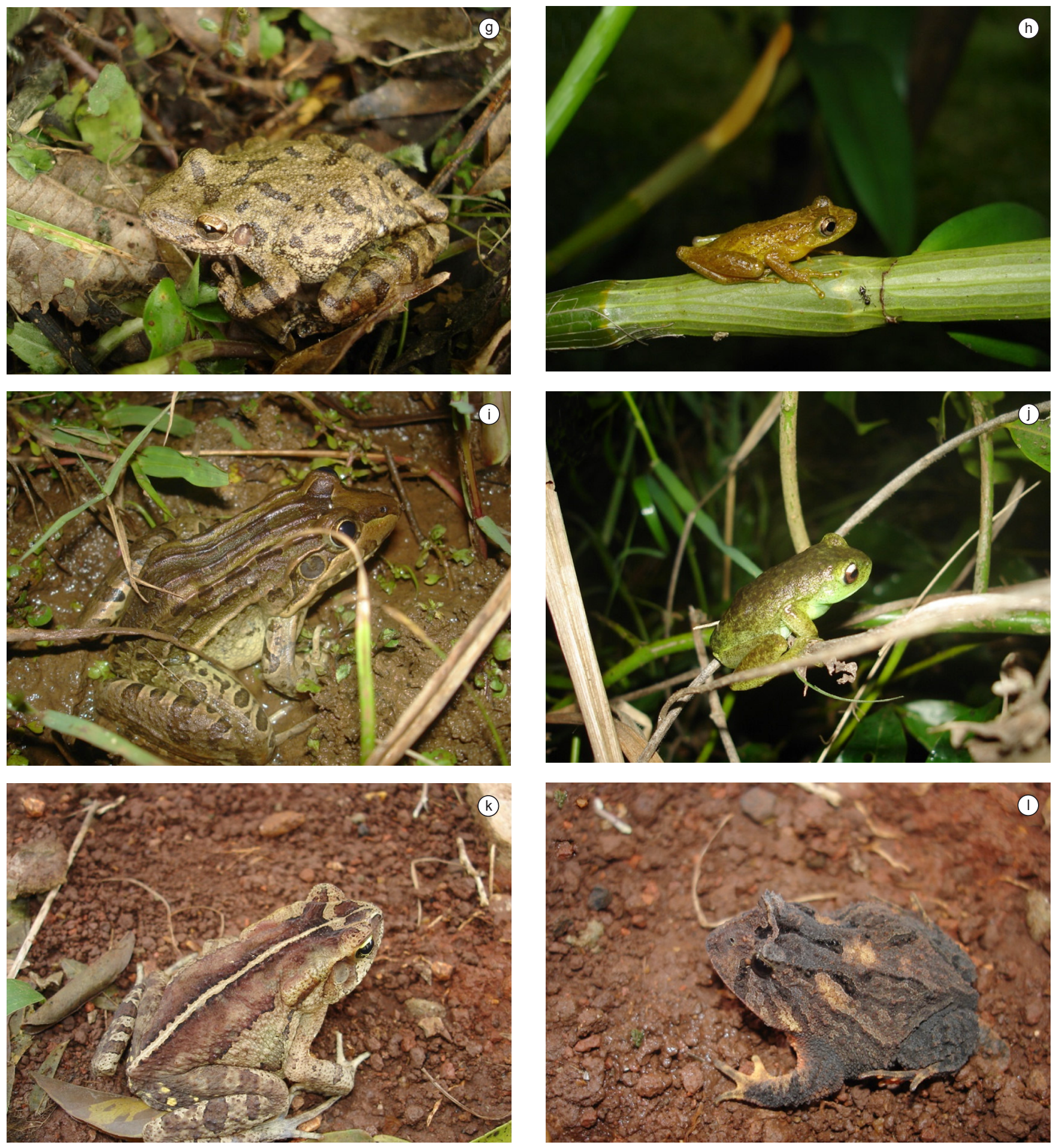

Appendix 1. Amphibian anuran species found in Floresta Nacional de Chapecó, Santa Catarina State, southern Brazil. a) Phyllomedusa tetraploidea, b) Hyalinobatrachium uranoscopum, c) Hypsiboas aff. semigutattus, d) Hypsiboas faber, e) Dendropsophus minutus, f) Limnomedusa macroglossa, g) Scinax fuscovarius, h) Scinax aromothyella, i) Leptodactylus cf. ocellatus, j) Aplastodiscus perviridis, k) Rhinella henseli, and 1) Proceratophrys bigibbosa. Photos: E.M. Lucas.

Apêndice 1. Anfíbios anuros registrados na Floresta Nacional de Chapecó, Estado Santa Catarina, sul do Brasil. a) Phyllomedusa tetraploidea, b) Hyalinobatrachium uranoscopum, c) Hypsiboas aff. semigutattus, d) Hypsiboas faber, e) Dendropsophus minutus, f) Limnomedusa macroglossa, g) Scinax fuscovarius, h) Scinax aromothyella, i) Leptodactylus cf. ocellatus, j) Aplastodiscus perviridis, k) Rhinella henseli, e 1) Proceratophrys bigibbosa. Fotos: E.M. Lucas. 